\title{
Role of photoperiod in reproductive maturation and peripubertal hormone concentrations in male collared lemmings (Dicrostonyx groenlandicus)
}

\author{
B. A. Gower ${ }^{1}$, T. R. Nagy ${ }^{2}$ and M. H. Stetson ${ }^{1}$ \\ 'School of Life and Health Sciences, University of Delaware, Newark, DE 19716, USA; and \\ ${ }^{2}$ Department of Biology, University of Utah, Salt Lake City, UT 84112, USA
}

\begin{abstract}
Summary. Onset of sexual maturation was determined in weanling male collared lemmings exposed to one of three experimental regimens of different photoperiods before and after weaning. Animals gestated in photoperiods of either $16 \mathrm{~h}$ light:8h dark or $8 \mathrm{~h}$ light: $16 \mathrm{~h}$ dark. Those from $16 \mathrm{~h}$ light: $8 \mathrm{~h}$ dark were transferred at 19 days of age to either $20 \mathrm{~h}$ light: $4 \mathrm{~h}$ dark or $8 \mathrm{~h}$ light: $16 \mathrm{~h}$ dark; those gestated under $8 \mathrm{~h}$ light: $16 \mathrm{~h}$ dark remained in that photoperiod throughout the experiment. After exposure for $15,20,25$ or 30 days to the postweaning photoperiod, animals were killed and the following parameters assessed: body weight, testes weight, seminal vesicle weight, the presence or absence of epididymal spermatozoa and serum concentrations of prolactin, testosterone and corticosterone. All parameters except serum testosterone were significantly influenced by photoperiod. Animals housed under $8 \mathrm{~h}$ light: $16 \mathrm{~h}$ dark had significantly greater body weights than those housed under $20 \mathrm{~h}$ light: $4 \mathrm{~h}$ dark, a response that differs from that reported for other arvicoline rodents. The group gestated on $16 \mathrm{~h}$ light: $8 \mathrm{~h}$ dark and transferred on day 19 to $8 \mathrm{~h}$ light: $16 \mathrm{~h}$ dark had lower testes and seminal vesicle weights than the other two groups, and mature spermatozoa in the epididymides appeared 5 days later than in the $20 \mathrm{~h}$ light: $4 \mathrm{~h}$ dark group. Serum prolactin was largely undetectable in animals from both $8 \mathrm{~h}$ light:16 h dark groups, but all males housed in $20 \mathrm{~h}$ light:4 h dark had $2 \cdot 0-15.0 \mathrm{ng}$ prolactin $\mathrm{ml}^{-1}$. Concentration of serum corticosterone was higher in animals weaned into long photoperiod, and decreased with age. These data indicate that weanling male $D$. groenlandicus are reproductively photoresponsive, but use a decrease in photoperiod, not static short-photoperiod exposure, to alter the rate of development. Prolactin was largely undetectable in animals exposed to short photoperiod, indicating that high concentrations of this hormone are not important for maturation. Low prolactin concentrations in animals in short photoperiods may mediate the annual moult to white pelage. The short-photoperiod-mediated decrease in corticosterone may play a role in seasonal changes in body weight and composition.
\end{abstract}

Kevwords: photoperiod; maturation; prolactin; testosterone; corticosterone; lemming

\section{Introduction}

Collared lemmings, Dicrostonyx groenlandicus, inhabit the holarctic regions, from Greenland west to Alaska, $60-70^{\circ} \mathrm{N}$ (Banfield, 1974) and consequently are exposed to dramatic seasonal changes in temperature and photoperiod. The breeding season reflects this temporally harsh and variable environment, generally spanning the months from March to August or September, with a hiatus in June during meltoff (Banfield, 1974; Negus \& Berger, 1987). Young born early in the breeding season mature and reproduce during the year of their birth, whereas those born later may 
overwinter and reproduce the following year (P. J. Berger and N. C. Negus, pers. commun). Observations of winter breeding in some years (Krebs, 1964; MacLean et al., 1974) suggest that this species is not strictly photoperiodic with respect to reproduction.

Arvicoline rodents (voles and lemmings) use photoperiod to time reproduction and to regulate growth and maturation. Breeding and maturation in the field and laboratory are optimal under conditions of long or increasing photoperiod (Clarke \& Forsyth, 1964; Pinter, 1968; Grocock \& Clarke, 1974; Hasler \& Banks, 1975; Nelson, 1987). Such responses to photoperiod have been observed in many rodent species (for reviews, see Zucker et al., 1980; Bronson, 1989) and are adaptive; production of offspring under long photoperiods results in the weaning of young during the time of year when food is most available and temperatures are most moderate, maximizing the chances of offspring successfully maturing and breeding. Additionally, the energy demands of lactating females are more easily met in seasons of the year when food is readily available. Arvicolines are reproductively opportunistic, however, and also breed when exposed to short or decreasing photoperiod if other environmental cues or conditions are present. Food, water, certain plant chemicals and social factors also affect reproduction in arvicoline species (Pinter \& Negus, 1965; Hasler, 1975; Berger et al., 1977, 1981; Nelson et al., 1983; Rissman \& Johnston, 1986; Negus \& Berger, 1987).

An earlier study (Hasler et al., 1976) examined various reproductive parameters in laboratoryhoused adult and weanling male and female $D$. groenlandicus transferred to long ( $20 \mathrm{~h} \mathrm{light:4 \textrm {h }}$

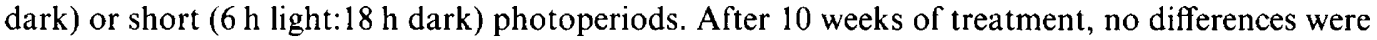
found in any of the indices of reproductive function assessed (weights of reproductive tissues, follicle size, epididymal spermatozoa, testosterone concentrations) and the authors concluded that this species was not reproductively photoresponsive; but weanlings were not examined during the period over which sexual maturation would be expected to occur (40-60 days of age, based on findings in other arvicoline species; Grocock, 1979; Kinch et al., 1986; Lee et al., 1987). Consequently, any possible photoperiod-related difference in the onset of maturation may not have been detected. Since the timing of maturation is an important event in the life history of short-lived rodents (Negus et al., 1977; Bronson, 1988), reproductive photoresponsiveness may be selectively manifested before puberty.

We determined the age of reproductive maturation in weanling male $D$. groenlandicus trans-

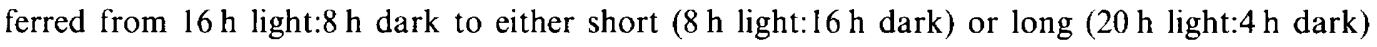
photoperiods. These lighting conditions are similar to those used by Hasler et al. (1976) and were chosen so that results of the two studies could be compared. The earlier study determined that, when examined as adults, lemmings were reproductively photoinsensitive; the present study examined photoresponsiveness in peripubertal animals. In addition to the above two regimens, we also examined animals gestated and raised in $8 \mathrm{~h}$ light: $16 \mathrm{~h}$ dark. These later conditions would convey short-photoperiod information to animals before and after birth. By using this additional photoperiod treatment and by examining animals at a particularly critical point in their development, we hoped to determine whether $D$. groenlandicus is truly photoinsensitive with respect to reproduction.

Sera from all experimental animals were analysed for prolactin and testosterone, the concentrations of which are known to be influenced by photoperiod in other species (Goldman et al., 1981; Blank \& Desjardins, 1986). Prolactin may play a role in sexual maturation in male golden hamsters (Stallings et al., 1985; Stroud et al., 1985) and appears to participate in the annual pelage colour cycle in Siberian hamsters (Duncan \& Goldman, 1984a; Duncan et al., 1985). Testosterone is important for reproductive development and function. We also quantified serum corticosterone, since, in arvicoline species, changes in adrenal size and function are associated with changes in environmental conditions, season, maturity and reproductive status (Chitty \& Clarke, 1963; Andrews \& Ryan, 1971; Andrews \& Strohbehn, 1971; Seabloom et al., 1978). The physiological significance of these changes is unknown. Corticosterone is involved in metabolic processes and, when present in high concentrations, can adversely influence reproductive function (Moberg, 1987). 


\section{Materials and Methods}

\section{Animals and photoperiods}

The male Dicrostonyx groenlandicus used in this study were obtained from a laboratory colony maintained at the Department of Biology, University of Utah, Salt Lake City, UT, USA. The colony was established from animals trapped at Igloolik Island, Northwest Territories, Canada $\left(69^{\circ} 23^{\prime} \mathrm{N}, 81^{\circ} 50^{\prime} \mathrm{W}\right)$. A breeding colony was maintained under a $16 \mathrm{~h}$ light: $8 \mathrm{~h}$ dark photoperiod and an ambient temperature of $18 \pm 1^{\circ} \mathrm{C}$. For the production of offspring under an $8 \mathrm{~h}$ light: $16 \mathrm{~h}$ dark photoperiod, mated pairs were transferred to that photoperiod 4 days after pairing.

At weaning ( 19 days old), male lemmings were caged in pairs. Those from the $16 \mathrm{~h}$ light: $8 \mathrm{~h}$ dark colony were transferred at random to either $8 \mathrm{~h}$ light: $16 \mathrm{~h}$ dark (short photoperiod) or $20 \mathrm{~h}$ light: $4 \mathrm{~h}$ dark (long photoperiod), whereas those from $8 \mathrm{~h}$ light:16 h dark remained in the natal photoperiod. Animals were housed in $57 \times 17 \times 15 \mathrm{~cm}^{3}$ fibreglass cages, fitted with hardware cloth lids, containing sawdust and cotton batting. Rabbit pellets (Intermountain Farmers Assoc., Salt Lake City, UT, USA) and water were available ad libitum.

\section{Hormone measurements}

Groups of six animals were killed midway through the photophase every 5 days from 33 to 48 days of age. A pilot experiment showed that sexual maturation, indicated by the presence of spermatozoa in the epididymides, occurred between 33 and 48 days of age. Animals were weighed to the nearest $0.01 \mathrm{~g}$ and testes and seminal vesicles were removed, blotted dry and weighed to the nearest $0.1 \mathrm{mg}$. Epididymides were removed, sectioned histologically and examined microscopically for the presence of spermatozoa. Trunk blood was collected at the time of death and sera were stored at $-20^{\circ} \mathrm{C}$ until analysed for prolactin, testosterone and corticosterone.

Prolactin was measured with a hamster prolactin kit (obtained from A. F. Parlow of the Pituitary Hormones and Antisera Center, Torrance, CA, USA). Reagents included rat antiserum to hamster prolactin (AFP-7472988), highly purified hamster prolactin for iodination (AFP-10302E) and hamster prolactin reference preparation (AFP-10302E). Antigen was iodinated (Iodine-125, ICN) with the chloramine T method, following the guidelines included with the kit, and added to each assay tube at 10000 c.p.m. Antiserum was used at a final tube dilution of 1:85000, which bound about $30 \%$ of the radioactivity added in an assay volume of $0.425 \mathrm{ml}$. The standard curve ranged from 0.02 to $5.0 \mathrm{ng}$. The lower limit of sensitivity, calculated as $90 \%$ bound using a regression equation, varied between assays from 0.01 to $0.03 \mathrm{ng}$. The intra- and interassay coefficients of variation were 3.3 and $7.8 \%$, respectively, based on repeated measures of a serum pool.

The prolactin assay was validated for use with $D$. groenlandicus sera by comparing the slope of serial dilutions of serum pools and pituitary homogenates, obtained from adult males, with the slope of the standard curve. The displacement curves produced by both were parallel to that produced by the hamster prolactin standard (Fig. 1a and b). Serum samples obtained from the juvenile males in the present experiment were assayed in duplicate at either $50 \mu \mathrm{l}$ (short-photoperiod animals) or $25 \mu$ l (long-photoperiod animals); these quantities were chosen from the results of a preliminary assay.

Additivity was determined by assaying $50 \mu \mathrm{l}$ aliquots of $D$. groenlandicus sera to which known amounts of hamster prolactin had been added. Recovery of hamster prolactin $(0.04,0.08,0 \cdot 16,0.3 \mathrm{I}$ and $0.625 \mathrm{ng})$, when added to D. groenlandicus sera, ranged from 100 to $121 \%$ (average $108 \%$ ).

The validations discussed above indicate that the anti-hamster prolactin antiserum crossreacts with prolactin in D. groenlandicus sera. Caution should be taken when comparing the prolactin concentrations reported here with those reported elsewhere for other species, since it is not known whether the antiserum binds prolactin with an affinity equal to that for the homologous hormone. Decreased antibody affinity for lemming prolactin, relative to hamster prolactin, would result in an underestimation of hormone content in lemming sera.

Serum testosterone was measured with antiserum S-250 (from G. D. Niswender) used at a dilution of 1:376000; $100 \mu \mathrm{l}$ of serum was extracted with $5 \mathrm{ml}$ dichloromethane, reconstituted in assay buffer $\left(0 \cdot 1 \mathrm{~mol}\right.$ phosphate buffer $\mathrm{l}^{-1}$, $1 \%$ gelatin, $1 \%$ sodium azide) and assayed in duplicate. Extraction recovery was $77 \%$ and values were not corrected for extraction losses. Samples were incubated for $24 \mathrm{~h}$ at $4^{\circ} \mathrm{C}$ after which bound and free hormone were separated with dextran-coated charcoal. The standard curve ranged from 3 to $400 \mathrm{pg}, 3 \mathrm{pg}$ being the lower limit of assay sensitivity ( $90 \%$ bound). Intra- and interassay coefficients of variation were 3.6 and $6.5 \%$, respectively.

Serum corticosterone was measured with antiserum B3-163 (from Endocrine Sciences, Tarzana, CA, USA) used at 1:120 320; $10 \mu \mathrm{l}$ of serum was diluted to $1 \mathrm{ml}$ in assay buffer (see above) and heat inactivated (at $65^{\circ} \mathrm{C}$ for $1 \mathrm{~h}$ ), after which $100 \mu \mathrm{l}$ aliquots were assayed in duplicate. Incubation and separation conditions were identical to those given for the testosterone assay. The standard curve ranged from 7.8 to $2000 \mathrm{pg}$. The lower limit of assay sensitivity was calculated to be $10 \mathrm{pg}(90 \%$ bound). Intra- and interassay coefficients of variation were 4.8 and $10 \%$, respectively.

Dilutions of a lemming serum pool were heat inactivated, as described for corticosterone and assayed for cortisol (for assay details, see Donham et al., 1988). Cortisol was undetectable in samples, which, when assayed for corticosterone, had concentrations ranging from 7 to $314 \mathrm{pg}$ ( 92 to $28 \%$ bound).

\section{Statistical analysis}

Body weights, testes weights, seminal vesicle weights, serum testosterone and serum corticosterone were analysed with a two-way ANOVA and a least-squares means test on log-transformed values (SAS Institute Inc., version 5). The 


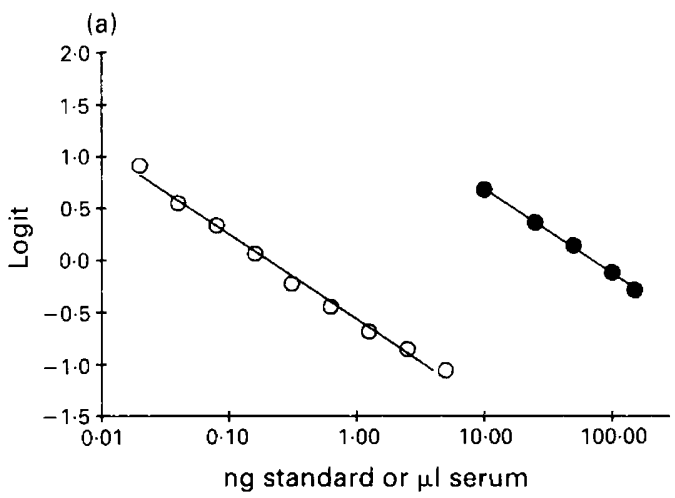

(b)

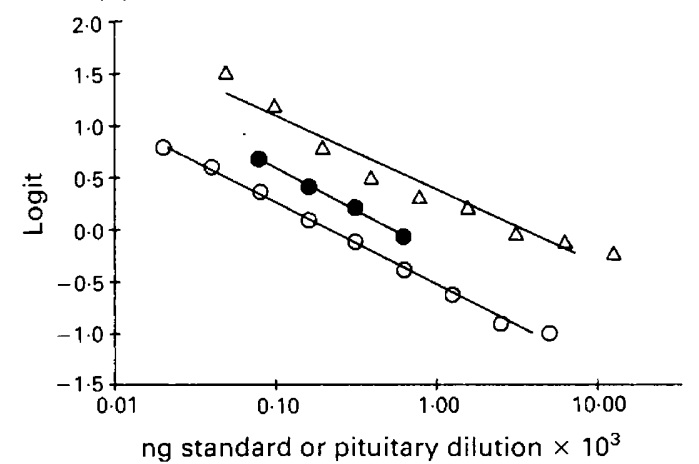

Fig. 1. Regression plots of displacement curves produced by (a) hamster prolactin reference preparation AFP-10302E $(O)$ and a Dicrostonyx groenlandicus serum pool (๑) (slopes = -0.81616 and -0.81568 , respectively) and (b) reference preparation and $D$. groenlandicus pituitary homogenates (slopes $=-0.78787,-0.81332$ and -0.71077 , for standard $(0)$, pituitaries from $8 \mathrm{~h}$ light: $16 \mathrm{~h}$ dark-housed animals $(\bullet)$ and pituitaries from $20 \mathrm{~h}$ light:4h dark-housed animals $(\triangle)$, respectively).

percentages of animals in each group showing epididymal spermatozoa were compared with $2 \times 2$ contingency tables. The proportion of detectable versus nondetectable prolactin values were compared between groups with $2 \times 2$ contingency tables. Since the samples from the $8 \mathrm{~h}$ light: $16 \mathrm{~h}$ dark to $8 \mathrm{~h}$ light:16 h dark group were assayed later than those from the other two groups, absolute prolactin values were not compared.

\section{Results}

\section{Body, testes and seminal vesicle weights}

Two-way analysis of variance showed that body weights were significantly affected by photoperiod and age (Fig. 2a, $P<0.0001$ ). Long-photoperiod animals differed, with respect to body weight, from both of the short-photoperiod groups $(P<0.0001)$. Body weights at 48 days of age were different from those at all other ages $(P<0.0001$ versus 33 and 38 days; $P<0.001$ versus 43 days). Testes weights were significantly affected by photoperiod and age (Fig. $2 \mathrm{~b}, P<0.0001$ ). The interaction of photoperiod and age was also significant $(P<0.005)$. Animals transferred to $8 \mathrm{~h}$ light: $16 \mathrm{~h}$ dark had tissue weights that differed from those of the other two groups $(P<0.0001)$. Testes from animals 43 and 48 days old were significantly different from those of animals 33 and 38 days old ( $P<0.01,43$ versus 33 days; $P<0.0001$, all other comparisons). Both photoperiod and age influenced seminal vesicle weights (Fig. 2 c, $P<0.0001$ ). The interaction of photoperiod and 
age was significant at $P<0.05$. Tissue weights from males transferred to $8 \mathrm{~h}$ light: $16 \mathrm{~h}$ dark were different from those of the other two groups $(P<0.0001)$. Seminal vesicles from animals 43 and 48 days of age were significantly different from those of animals 33 and 38 days of age $(P<0.0005,43$ versus 38 days; $P<0.0001$, all other comparisons). Spermatozoa were not found in the epididymides from 33 or 38-day-old males of any photoperiod (Fig. 2b). Males in long photoperiods all had epididymal spermatozoa at 43 days of age, whereas only $33 \%$ of those animals transferred to short photoperiod had spermatozoa at this age; this difference was significant $(P<0 \cdot 05)$. The group raised under $8 \mathrm{~h}$ light: $16 \mathrm{~h}$ dark did not differ from either of the other two groups. At 48 days of age, $83 \%$ of males transferred to $8 \mathrm{~h}$ light: $16 \mathrm{~h}$ dark had epididymal spermatozoa; this is not significantly different from the $100 \%$ observed in males housed under $20 \mathrm{~h}$ light: $4 \mathrm{~h}$ dark or raised under $8 \mathrm{~h}$ light: $16 \mathrm{~h}$ dark.

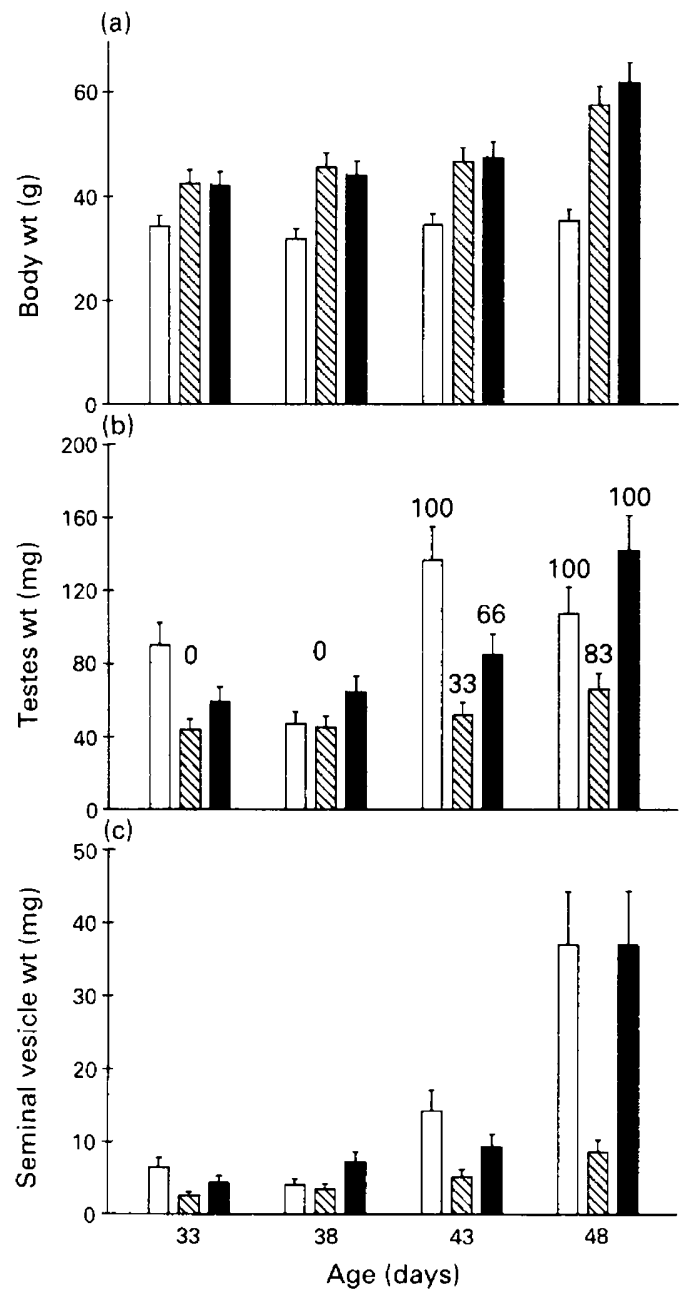

Fig. 2. (a) Body weights, (b) testes weights and percentage of animals in each group with epididymal spermatozoa and (c) seminal vesicle weights at the time of death in Dicrostonyx groenlandicus. ( $\square$ ) $16 \mathrm{~h}$ light: $8 \mathrm{~h}$ dark-20 h light: $4 \mathrm{~h}$ dark, ( $(1) 16 \mathrm{~h}$ light: $8 \mathrm{~h}$ dark-8 h light: $16 \mathrm{~h}$ dark, ( $8 \mathrm{~h}$ light:16 h dark-8 h light:16 h dark. See Results for significant differences between groups. Data are means \pm SEM. 
Table 1. Effects of photoperiod treatment on serum prolactin $\left(\mathrm{ng} \mathrm{m}^{-1}\right)$ in male collared lemmings

\begin{tabular}{|c|c|c|c|}
\hline \multirow[b]{2}{*}{$\begin{array}{l}\text { Age } \\
\text { (days) }\end{array}$} & $\begin{array}{l}16 \mathrm{~h} \text { light: } 8 \mathrm{~h} \text { dark-- } \\
20 \mathrm{~h} \text { light: } 4 \mathrm{~h} \text { dark }\end{array}$ & $\begin{array}{c}\text { Photoperiod } \\
16 \mathrm{~h} \text { light: } 8 \mathrm{~h} \text { dark- } \\
8 \mathrm{~h} \text { light: } 16 \mathrm{~h} \text { dark }\end{array}$ & $\begin{array}{l}8 \mathrm{~h} \text { light: } 16 \mathrm{~h} \text { dark- } \\
8 \mathrm{~h} \text { light: } 16 \mathrm{~h} \text { dark }\end{array}$ \\
\hline & $\begin{array}{c}\text { Number detectable } / n \\
\text { Mean } \pm \text { SEM }^{\mathrm{a}}\end{array}$ & $\begin{array}{l}\text { Number detectable } / n \\
\quad \text { Mean } \pm \text { SEM }^{\mathrm{a}}\end{array}$ & $\begin{array}{l}\text { Number detectable } / n \\
\text { Mean } \pm \mathrm{SEM}^{\mathrm{a}}\end{array}$ \\
\hline 33 & $6 / 6+$ & $1 / 6$ & $1 / 6$ \\
\hline & $5 \cdot 1 \pm 0 \cdot 4$ & 0.6 & 6.8 \\
\hline 38 & $6 / 6+$ & $0 / 6^{\mathrm{b}}$ & $2 / 6$ \\
\hline & $4 \cdot 1 \pm 0.2$ & & $4 \cdot 0 \pm 1 \cdot 0$ \\
\hline 43 & $6 / 6 \dagger$ & $2 / 6$ & $1 / 6$ \\
\hline & $4.4 \pm 0.8$ & $2 \cdot 6 \pm 2 \cdot 1$ & $2 \cdot 2$ \\
\hline 48 & $\begin{array}{c}6 / 6+ \\
5.6 \pm 1.9\end{array}$ & $0 / 6^{b}$ & $0 / 6^{c}$ \\
\hline
\end{tabular}

$\uparrow$ Significantly different from both $8 \mathrm{~h}$ light: $16 \mathrm{~h}$ dark groups.

${ }^{a}$ Mean \pm SEM of detectable values only.

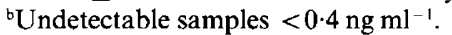

'Undetectable samples $<0.6 \mathrm{ng} \mathrm{ml}^{-1}$.

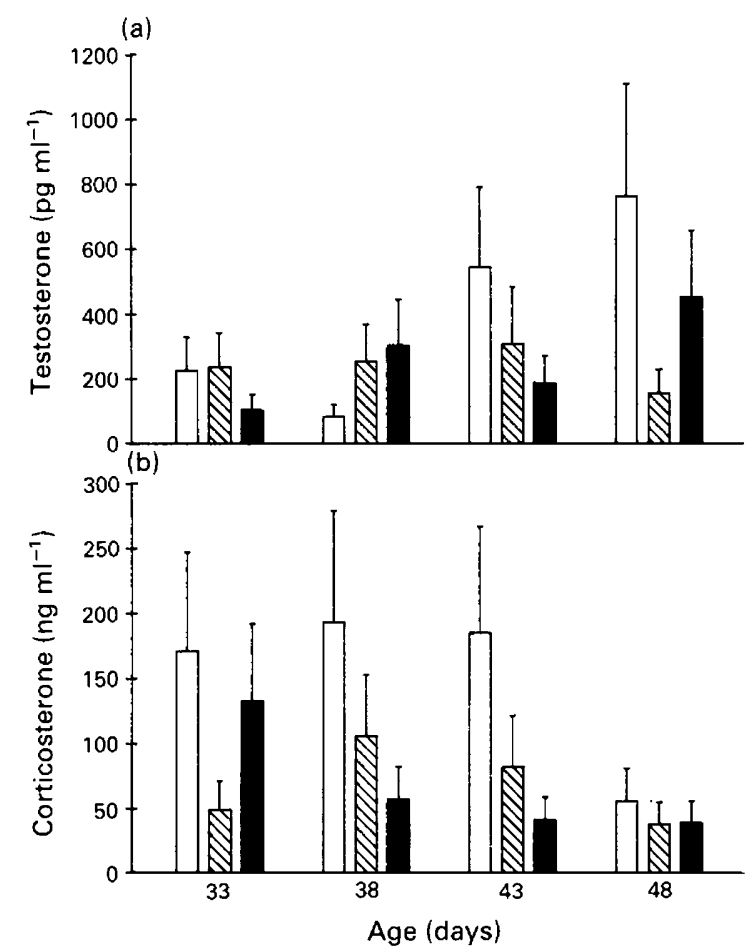

Fig. 3. Concentration of (a) testosterone and (b) corticosterone in serum of Dicrostonyx

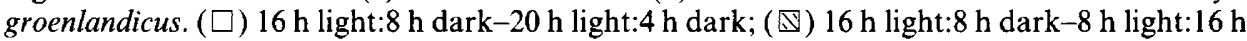
dark; ( ) $8 \mathrm{~h}$ light:16h dark-8 h light:16 h dark. Data are means \pm SEM. $n=6$ for all groups except $16 \mathrm{~h}$ light: $8 \mathrm{~h}$ dark-8 h light: $16 \mathrm{~h}$ dark at age 43 days where $n=4$. 


\section{Hormone concentrations}

Prolactin concentrations were significantly influenced by photoperiod (Table $1, P<0.05$, $20 \mathrm{~h}$ light: $4 \mathrm{~h}$ dark versus both $8 \mathrm{~h}$ light: $16 \mathrm{~h}$ dark groups). All males in long photoperiods had detectable concentrations of prolactin, but only seven of the 48 lemmings housed under short photoperiod had a measurable hormone content.

Serum testosterone was not influenced by photoperiod or age alone (Fig. 3a, $P>0.05$ ), but the interaction of the two parameters was significant $(P<0.05)$.

Both photoperiod and age influenced serum corticosterone concentration (Fig. $3 b, P<0.05$ ). Males in long photoperiods differed from males raised in $8 \mathrm{~h}$ light: $16 \mathrm{~h}$ dark $(P<0.01)$ and those transferred to $8 \mathrm{~h}$ light: $16 \mathrm{~h}$ dark $(P<0.05)$. Serum corticosterone concentration of 48-day-old males differed from that of 33 and 38-day-old animals $(P<0.05)$.

\section{Discussion}

The present study was designed to determine whether photoperiod influences the timing of reproductive maturation in male collared lemmings. An effect of photoperiod on maturation has been documented in males of several species of arvicoline rodents (Microtus pennsylvanicus: Lee et al., 1987; M. agrestis: Grocock, 1979; Kinch et al., 1986; M. ochrogaster: Nelson, 1985). In these studies, the appearance of mature spermatozoa was delayed by up to 200 days by exposure to short photoperiod.

The findings presented here clearly demonstrate that weanling male $D$. groenlandicus are also photoresponsive with respect to reproduction. Testes and seminal vesicle weights and the proportion of animals showing epididymal spermatozoa were significantly influenced by photoperiod. This conclusion contrasts with that of Hasler et al. (1976), who found no effect on reproductive parameters of exposure to similar photoperiod manipulations at weaning or during adulthood. In this earlier study, however, animals were examined only after 70 days of exposure to the experimental photoperiods. It is possible that, after 70 days, any photoperiodically induced differences in reproductive parameters present early in the treatment period may have disappeared. Our data support this possibility in that the onset of fertility, as indicated by the appearance of spermatozoa in the epididymides, was delayed by only 5 days in animals transferred to $8 \mathrm{~h}$ light: $16 \mathrm{~h}$ dark (present study), while animals switched to $8 \mathrm{~h}$ light: $16 \mathrm{~h}$ dark at weaning and examined after 70 days all had mature epididymal spermatozoa (B. A. Gower \& T. R. Nagy, unpublished).

Although, in the present experiment, the effect of photoperiod on the timing of fertility onset was significant, the ecological, or functional, importance of this 5 day delay is not obvious. The possibility exists that, under natural conditions, the reproductive response to a reduction in photoperiod may be more dramatic. When reduced photoperiod occurs simultaneously with reductions in temperature and food quality at the onset of the arctic autumn, maturation in juveniles and reproductive activity in adults may slow or cease. In support of this hypothesis, reproductive activity and gonadal function were compromised when adult lemmings were cold-stressed (Quay, 1960 ). Mated $D$. groenlandicus pairs failed to produce young when housed at -9 to $-5^{\circ} \mathrm{C}$, and follicular maturation in females was depressed.

Alternatively, maturation in males may not be strongly affected by environmental factors. Natural selection often has allowed evolution of systems in which, because of the energy constraints associated with reproduction, the timing of puberty in the female is regulated more stringently by environmental conditions than is that of the male (Bronson, 1988). Consequently, further experimentation may find that peripubertal female $D$. groenlandicus show a more pronounced reproductive response to environmental factors than do males.

Only animals that experienced a decrease in photoperiod, not those raised under short photoperiod, responded to $8 \mathrm{~h}$ light: $16 \mathrm{~h}$ dark with a depressed rate of maturation. Dicrostonyx groenlandicus have been shown to respond to a decrease in photoperiod with depressed reproductive function. When mated pairs acclimatized to $24 \mathrm{~h}$ light were transferred to $14 \mathrm{~h} \mathrm{light:10 \textrm {h }}$ 
dark, the mean number of litters produced and the mean litter size were reduced when compared with pairs remaining in $24 \mathrm{~h}$ light (Negus \& Berger, 1987). A preferential response to a change in photoperiod, rather than the absolute number of hours of light per day, might be adaptive for a species inhabiting latitudes at which it experiences rapid seasonal changes in photoperiod.

In the present study, lemmings maintained under constant short photoperiod matured more rapidly than those transferred from $16 \mathrm{~h}$ light: $8 \mathrm{~h}$ dark to $8 \mathrm{~h}$ light:16 h dark. Since the critical daylengths for triggering short-photoperiod responses have not been determined in this species, we can only speculate as to the ecological relevance of the above-mentioned photoperiod manipulations. Static short-photoperiod treatment in the laboratory may simulate the natural arctic autumn/winter photoperiod $\left(6-8 \mathrm{~h}\right.$ light $\mathrm{day}^{-1}$, including civil twilight, from 17 November to 25 January at $66^{\circ} \mathrm{N}$; Nautical Almanac Office, 1991). Selection may favour rapid maturation in animals born under these conditions in preparation for spring breeding. The animals switched from long to short photoperiod experienced a decrease in daylength similar to that which occurs in the arctic from 6 September to 17 November ( $16 \mathrm{~h}$ light: $8 \mathrm{~h}$ dark to $8 \mathrm{~h}$ light: $16 \mathrm{~h}$ dark). Since collared lemmings cease reproducing in August or September, young born in late summer might be expected to mature at a slower rate, possibly under the influence of decreasing photoperiod.

The increase in photoperiod, from $16 \mathrm{~h}$ light: $8 \mathrm{~h}$ dark to $20 \mathrm{~h}$ light: $4 \mathrm{~h}$ dark, experienced by lemmings in this study, simulates photoperiod changes that would be observed in the natural situation by animals born on 1 April ( $16 \mathrm{~h}$ light: $8 \mathrm{~h}$ dark). These animals would observe a $20 \mathrm{~h}$ light: $4 \mathrm{~h}$ dark photoperiod on 28 April and would reach sexual maturity during the next few weeks. Lemmings with this life history mature rapidly, possibly under the influence of increasing photoperiod, and can breed in the year of their birth. Work underway to determine critical photoperiods in collared lemmings may help in understanding the roles of relative and absolute daylength in seasonal physiological changes in this species.

In the present experiment and in that of Hasler et al. (1976), young lemmings exposed to a short photoperiod showed a significant increase in body weight. The decrease in surface to volume ratio resulting from this increase in weight may be of benefit to a small mammal exposed to low temperatures for a long period of the year. This strategy for coping with low winter temperatures differs from that of other arvicoline rodents, which show either a decrease in body weight or growth rate when exposed to decreased or short photoperiod (Horton, 1984; Rhodes, 1989), or no body weight response to changes in photoperiod (Grocock, 1979).

Lemmings also show photoperiod-dependent differences in body composition. Although body weight is increased by short-photoperiod exposure, the relative amount of body fat decreases (Hasler et al., 1976; Nagy, 1992); the mechanism for this change is unknown. In the present study, we observed significant differences in serum corticosterone concentration between animals housed in long and short photoperiods. This hormone influences various metabolic processes, including lipid mobilization and glucose utilization (Granner, 1988) and may play a role in the seasonal changes in body weight and composition observed in D. groenlandicus. High glucocorticoid concentrations depress growth in rats (Wehrenberg et al., 1990), suggesting that the decrease in corticosterone associated with short-photoperiod exposure in lemmings may allow the observed increase in growth rate. The reduced corticosterone observed in animals housed in $8 \mathrm{~h}$ light:16 h dark may also be involved with thermogenic adjustments. In rats and mice, depression of circulating glucocorticoids, via pharmacological means or adrenalectomy, stimulated brown adipose tissue activity (Hardwick et al., 1989; Kim \& Romsos, 1990), a response which prevented obesity in genetically obese mice. Consequently, the short-photoperiod-induced decline in serum corticosterone observed in D. groenlandicus may facilitate thermogenesis, a response which would have adaptive value in the autumn and winter, when ambient temperature is low, and may explain the change in body composition observed in animals housed in short photoperiods.

In the present study, serum corticosterone also tended to decrease with maturation. Similar age-related changes in adrenal corticosteroid production were observed in golden hamsters (Donham et al., 1988), brown lemmings, Lemmus trimucronatus (Andrews et al., 1975) and 
marmots (Armitage, 1991). The physiological significance of these changes is unknown, although the negative effects of glucocorticoids on reproductive function may suggest that a peripubertal decrease in these hormones is permissive to sexual maturation.

Serum prolactin concentration was significantly depressed in lemmings exposed to short photoperiod, when compared with animals housed under long photoperiod. An effect of photoperiod on prolactin has been well documented in hamsters (Bex et al., 1978; Goldman et al., 1981; Duncan et al., 1985) and in deer mice (Blank \& Desjardins, 1986). Photoperiodically induced seasonal changes in prolactin are thought to influence gonadal maturation and regression. Treatment of photoregressed adult male hamsters with exogenous prolactin stimulated testicular growth (Bex et al., 1978), as did treatment of juveniles with ectopic pituitary transplants (Stallings et al., 1985). Treatment of juvenile males with bromocryptine, a dopamine agonist which depresses endogenous prolactin, retarded maturation (Stallings et al., 1985; Stroud et al., 1985). The results of the present study, however, suggest that, in D. groenlandicus, high concentrations of prolactin are not necessary for the maturation process. This observation may indicate a different role for prolactin in this reproductively opportunistic arvicoline rodent when compared with the highly photoperiodic hamster.

Photoperiod-related changes in prolactin also appear to contribute to the seasonal moults observed in Siberian hamsters (Phodopus sungorus). In the laboratory, adult male Siberian hamsters begin to develop a white pelage about 8 weeks after transfer to short photoperiod (Duncan \& Goldman, 1984b), whereas animals transferred to $8 \mathrm{~h}$ light: $16 \mathrm{~h}$ dark at birth begin to moult between 30 and 40 days of age (Hoffmann, 1978). When treated with bromocryptine, longphotoperiod-housed, castrated, Siberian hamsters developed a white winter pelage, and hamsters refractory to short photoperiod failed to develop the summer pelage (Duncan \& Goldman, 1984a). Dicrostonyx groenlandicus also moults to a white winter pelage when exposed to short photoperiod. In the present experiment, the animals raised in $8 \mathrm{~h}$ light: $16 \mathrm{~h}$ dark developed a white pelage immediately after birth, and those transferred to $8 \mathrm{~h}$ light: $16 \mathrm{~h}$ dark at 19 days of age were in the process of moulting to the winter pelage at the time of death (33-48 days of age). Serum prolactin was largely undetectable in all age groups of lemmings housed under $8 \mathrm{~h}$ light: $16 \mathrm{~h}$ dark, indicating that, at most, 15 days of short photoperiod exposure is required to cause a decline in the hormone. This time course is similar to that observed in male P. sungorus (Matt et al., 1990). The alteration of serum prolactin by photoperiod may mediate seasonal pelage colour changes in lemmings and Siberian hamsters.

In neither the present study nor in that of Hasler et al. (1976) was an effect of photoperiod on testosterone observed; concentrations were similar in the two studies. One would expect testosterone concentration to reflect the weights of testes and seminal vesicles, and therefore to be lower in animals transferred to $8 \mathrm{~h}$ light: $16 \mathrm{~h}$ dark. The lack of such a correlation in this study may reflect the large amount of variability present in the serum testosterone concentrations.

The results indicate that growth of reproductive and somatic tissues and the timing of maturation in male $D$. groenlandicus are influenced by changes in photoperiod after weaning. The effect of photoperiod alone on the timing of maturation is slight, however, and may not be functionally significant. This observation suggests that $D$. groenlandicus is reproductively opportunistic, or facultative, rather than obligately photoperiodic (Negus \& Berger, 1972) and may use a combination of environmental cues for timing maturation and breeding. Since other physiological parameters (body weight and composition) respond dramatically to photoperiod, $D$. groenlandicus appears to have uncoupled the regulation of the metabolic and reproductive systems. Serum prolactin was reduced to undetectable concentrations in male $D$. groenlandicus by exposure to $8 \mathrm{~h}$ light: $16 \mathrm{~h}$ dark, suggesting that prolactin is not important for maturation in this species. However, seasonal changes in the concentration of this hormone may play a role in the annual pelage cycle. The observed decrease in serum corticosterone in animals housed in short photoperiods may be important for seasonal changes in body composition or thermogenesis. 
This research was supported by NSF grant no. DCB87-14638 (M. H. Stetson) and an American Society of Mammalogists Grant-in-aid (T. R. Nagy). The prolactin radioimmunoassay kit was supplied by A. F. Parlow, Director, Pituitary Hormones and Antisera Center, Harbor-UCLA Medical Center. The testosterone antiserum was a generous gift of $G$. N. Niswender, Colorado State University, Ft Collins, CO. The authors wish to thank N. C. Negus, P. J. Berger, C. N. Rowsemitt, and two anonymous reviewers for their helpful comments on an earlier version of this manuscript, and R. S. Donham for technical assistance with the radioimmunoassays.

\section{References}

Andrews, R.V. \& Ryan, K. (1971) Seasonal changes in lemming pituitary-adrenal response to cold exposure. Comparative Biochemistry and Physiology 40A, 979-985.

Andrews, R.V. \& Strohbehn, R. (1971) Endocrine adjustments in a wild lemming population during the 1969 summer season. Comparative Biochemistry and Physiology 38A, 183-201.

Andrews, R.V., Ryan, K., Strohbehn, R. \& Ryan-Kline, M. (1975) Physiology and demographic profiles of brown lemmings during their cycle of abundance. Physiological Zoology 48, 64-81.

Armitage, K.B. (1991) Factors affecting corticosteroid concentrations in yellow-bellied marmots. Comparative Biochemistry and Physiology 98A, 47-54.

Banfield, A.W.F. (1974) The Mammals of Canada, pp. 193-197. University of Toronto Press, Toronto.

Berger, P.J., Sanders, E.H., Gardner, P.D. \& Negus, N.C. (1977) Phenolic plant compounds functioning as reproductive inhibitors in Microtus montanus. Science 195, 575-577.

Berger, P.J., Negus, N.C., Sanders, E.H. \& Gardner, P.D. (1981) Chemical triggering of reproduction in Microtus montanus. Science 214, 69-70.

Bex, F., Bartke, A., Goldman, B.D. \& Dalterio, S. (1978) Prolactin, growth hormone, luteinizing hormone receptors, and seasonal changes in testicular activity in the golden hamster. Endocrinology 103, 20692080 .

Blank, J.L. \& Desjardins, C. (1986) Photic cues induce multiple neuroendocrine adjustments in testicular function. American Journal of Physiology 250, R199-R206.

Bronson, F.H. (1988) Seasonal regulation of reproduction in mammals. In The Physiology of Reproduction, pp. 1831-1871. Eds E. Knobil \& J. Neill. Raven Press, New York.

Bronson, F. H. (1989) Mammalian Reproductive Biology. University of Chicago Press, Chicago.

Chitty, H. \& Clarke, J.R. (1963) The growth of the adrenal gland of laboratory and field voles, and changes in it during pregnancy. Canadian Journal of Zoology 41, 1025-1034.

Clarke, J.R. \& Forsyth, I.A. (1964) Seasonal changes in the gonads and accessory reproductive organs of the vole (Microtus agrestis). General and Comparative Endocrinology 4, 233-242.

Donham, R.S., Rollag, M.D. \& Stetson, M.H. (1988) Daily rhythms of pituitary ovarian functions in the immature hamster are independent of adrenal and pineal influence. Journal of Reproduction and Fertility 83, 809-818.
Duncan, M.J. \& Goldman, B.D. (1984a) Hormonal regulation of the annual pelage color cycle in the Djungarian hamster, Phodopus sungorus. II. Role of prolactin. Journal of Experimental Zoology 230, 97-103.

Duncan, M.J. \& Goldman, B.D. (1984b) Hormonal regulation of the annual pelage color cycle in the Djungarian hamster, Phodopus sungorus. I. Role of the gonads and the pituitary. Journal of Experimental Zoology 230, 89-95.

Duncan, M.J., Goldman, B.D., DiPinto, M.N. \& Stetson, M.H. (1985) Testicular function and pelage color have different critical daylengths in the Djungarian hamster, Phodopus sungorus sungorus. Endocrinology 116, 424-430.

Goldman, B.D., Matt, K.S., Roychoudhury, P. \& Stetson, M.H. (198I) Prolactin release in golden hamsters: photoperiod and gonadal influences. Biology of Reproduction 24, 287-292.

Granner, D.K. (1988) Hormones of the adrenal cortex. In Harper's Biochemistry, pp. 511-523. Appleton and Lange, Norwalk, CT.

Grocock, C.A. (1979) Testis development in the vole, Microtus agrestis, subjected to long or short photoperiods from birth. Journal of Reproduction and Fertility 55, 423-427.

Grocock, C.A. \& Clarke, J.R. (1974) Photoperiodic control of testis activity in the vole, Microtus agrestis. Journal of Reproduction and Fertility 39, 337-347.

Hardwick, A.J., Linton, E.A. \& Rothwell, N.J. (1989) Thermogenic effects of the antiglucocorticoid RU486 in the rat: involvement of corticotropin-releasing factor and sympathetic activation of brown adipose tissue. Endocrinology 124, 1684-1688.

Hasler, J.F. (1975) A review of reproduction and sexual maturation in the microtine rodents. Biologist 57, 52-86.

Hasler, J.F. \& Banks, E.M. (1975) Reproductive performance and growth in captive collared lemmings (Dicrostonyx groenlandicus). Canadian Journal of Zoology 53, 777-787.

Hasler, J.F., Buhl, A.E. \& Banks, E.M. (1976) The influence of photoperiod on growth and sexual function in male and female collared lemmings (Dicrostonyx groenlandicus). Journal of Reproduction and Fertility 46, 323-329.

Hoffmann, K. (1978) Effects of short photoperiods on puberty, growth and moult in the Djungarian hamster (Phodopus sungorus). Journal of Reproduction and Fertility 54, 29-35.

Horton, T.H. (1984) Growth and maturation in Microtus montanus: effects of photoperiods before and 
after weaning. Canadian Journal of Zoology 62 , 1741-1746.

Kim, H. \& Romsos, D.R. (1990) Adrenalectomy increases brown adipose tissue metabolism in ob/ob mice housed at $35^{\circ} \mathrm{C}$. American Journal of Physiology 259, E362-E369.

Kinch, R.F.T., Craven, R.P. \& Follet, B.K. (1986) Effects of age and photoperiod on the responsiveness of the pituitary gland of the vole (Microtus agrestis) to stimulation by GnRH. Journal of Reproduction and Fertility 76, 75-82.

Krebs, C.J. (1964) The lemming cycle at Baker Lake, Northwest Territories, during 1959-62. Arctic 15, $1-104$.

Lee, T.M., Smale, L., Zucker, I. \& Dark, J. (1987) Influence of daylength experienced by dams on postnatal development of young meadow voles (Microtus pennsylvanicus). Journal of Reproduction and Fertility 81, 337-342.

MacLean, S.F., Jr, Fitzgerald, B.M. \& Pitelka, F.A. (1974) Population cycles in arctic lemmings: winter reproduction and predation by weasels. Arctic and Alpine Research 6, 1-12.

Matt, K.S., Schoech, S. \& Morgan, S. (1990) Neuroendocrine and endocrine correlates of pair bonds and parental care in the seasonal reproductive cycle of the Siberian hamster Phodopus sungorus. In Progress in Comparative Endocrinology, Vol. 342, pp. 648-652. Eds A. Epple, C. G. Scanes \& M. H. Stetson. WileyLiss, Inc., New York.

Moberg, G.P. (1987) Influence of the adrenal axis upon the gonads. In Oxford Reviews of Reproductive Biology, Vol. 9, pp. 456-496. Ed. J. R. Clarke, Oxford University Press, New York.

Nagy, T.R. (1991) Environmental effects on energy acquisition and allocation in male collared lemmings, Dicrostonyx groenlandicus. Ph.D. thesis, University of Utah, Salt Lake City.

Nautical Almanac Office (1991) The Astronomical Almanac for the year 1992, pp. A12-A29. US Government Printing Office. Washington DC.

Negus, N.C. \& Berger, P.J. (1972) Environmental factors and reproductive processes in mammalian populations. In Biology of Reproduction, Basic and Clinical Studies, pp. 89-98. Eds J. T. Velardo \& B. A. Kasprow. Third Pan American Congress of Anatomy, Sponsored Symposium on Reproductive Biology. New Orleans, LA.

Negus, N.C. \& Berger, P.J. (1987) Mammalian reproductive physiology. Adaptive responses to changing environments. In Current Mammalogy, Vol. 1, pp. 149-173. Ed. H. H. Genoways. Plenum Publishing Corp., New York

Negus, N.C., Berger, P.H. \& Forslund, L.D. (1977) Reproductive strategy of Microtus montanus. Journal of Mammalogy 58, 347-353.
Nelson, R.J. (1985) Photoperiod influences reproduction in the prairie vole, Microtus ochrogaster. Biology of Reproduction 33, 596-602.

Nelson, R.J. (1987) Photoperiod-nonresponsive morphs: a possible variable in microtine population-density fluctuations. American Naturalist 130, 350-369.

Nelson, R.J., Dark, J. \& Zucker, I. (1983) Influence of photoperiod, nutrition and water availability on reproduction of male California voles (Microtus californicus). Journal of Reproduction and Fertility 69, 473-477.

Pinter, A.J. (1968) Effects of diet and light on growth, maturation, and adrenal size of Microtus montanus. American Journal of Physiology 215, 461-466.

Pinter, A.J. \& Negus, N.C. (1965) Effects of nutrition and photoperiod on reproductive physiology of Microtus montanus. American Journal of Physiology 208, 633-638.

Quay, W.B. (1960) The reproductive organs of the collared lemming under diverse temperature and light conditions. Journal of Mammalogy 41, 74-89.

Rhodes, D.H. (1989) The influence of multiple photoperiods and pinealectomy on gonads, pelage and body weight in male meadow voles, Microtus pennsylvanicus. Comparative Biochemistry and Physiology 93A, 445-449.

Rissman, E.F. \& Johnston, R.E. (1986) Nutritional and social cues influence the onset of puberty in California voles. Physiology and Behaviour 36, 343-347.

Seabloom, R.W., Iverson, S.L. \& Turner, B.N. (1978) Adrenal response in a wild Microtus population: seasonal aspects. Canadian Journal of Zoology 56, 1433-1440.

Stallings, M.H., Matt, K.S., Amador, A., Bartke, A., Siler-Khodr, T.M., Soares, M.J. \& Talamantes, F. (1985) Regulation of testicular LH-hCG receptors in golden hamsters (Mesocricetus auratus) during development. Journal of Reproduction and Fertility 75, $663-670$.

Stroud, C.M., Noden, P.F. \& Whitsett, J. Mal (1985) Bromocryptine decreases serum prolactin and delays sexual maturation in male golden hamsters. Biology of Reproduction 32, 1191-1199.

Wehrenberg, W.B., Bergman, P.J., Stagg, L., Ndon, J. \& Giustina, A. (1990) Glucocorticoid inhibition of growth in rats: partial reversal with somatostatin antibodies. Endocrinology 127, 2705-2708.

Zucker, I., Johnston, P.G. \& Frost, D. (1980) Comparative, physiological and biochronometric analyses of rodent seasonal reproductive cycles. Progress in Reproductive Biology 5, 102-133.

Received 29 July 1991 